\title{
Sustainable Development and Quality of Life in the City on the Example of Research in Poland and Ukraine
}

\author{
Hubert Kotarski ${ }^{1}$
}

\begin{abstract}
The issue of sustainable development combined with the quality of life of the inhabitants is one of the key problems of modern cities. Poland and Ukraine are two closest neighbours. Rzeszow and Lviv are both university cities, which are also partner cities. The main aim of the research was to learn the opinions of students of the University of Rzeszow and the Ivan Franko University of Lviv on selected problems related to the quality of life in Rzeszow and Lviv, as well as personal and professional aspirations of students in Poland and the Ukraine. The purpose of the study was both cognitive and practical, i.e. on the one hand it focused on obtaining information on specific topics related to various aspects of the quality of life in the city and the aspirations of young people, and on the other hand it attempted at obtaining information that could be useful for both university and city authorities in the context of exploiting the significant potential of young people living in these cities.
\end{abstract}

Keywords: sustainable development, quality of life, students, Poland, Ukraine

\section{Introduction}

The idea of sustainable development emerged as an attempt to respond to a set of threats, which in the 1960s were perceived in the predicted high demographic growth, rapid consumption of natural resources, increasing environmental pollution, failure to meet the basic needs of growing groups of people and deep destabilization of natural and socio-economic systems. The expression sustainable development was used in the late $1960 \mathrm{~s}$ by Barbara Ward to express the view that socio-economic development and environmental protection must be carried out together (Leisinger 1998: 73). This term became very popular after the World Commission on Environment and Development published its report in 1987. Sustainable development was described in this report, among other things, as "meeting current needs without compromising the ability to meet future needs and aspirations" (Nasza 1991: 64). The great popularity of this concept was not conducive to its unambiguity. By 1989, more than 60 different definitions of the term had been created (Pearce, Markandya \& Barbier 1989) and more are still being created (Moffatt 1996: 27). Additional publicity and broad acceptance of the idea of sustainable development came about as a result of the UN conference "Environment and Development" in Rio de Janeiro in 1992 and the international activities initiated by this conference, referred to as "Agenda 21" (Keating 1993). Nowadays, the term "sustainable development" is used to describe a concept whose most frequently formulated postulate is such economic and social development that it will not disturb ecosystems in which humans function. It is generally accepted that the processes taking place in these ecosystems depend on whether they maintain a balance favourable to the life and development of societies. Interpretations of these processes emphasizing the interdependence and equivalence of natural, social and economic changes are included in 
many publications and international documents concerning sustainable development (Serageldin 1995: 25; UNCSD 1997; Barber 2003). Nowadays, the statement assuming that social development is a necessary element of sustainable development, understood, among other things, as a reduction of social inequalities occurring today, becomes very important (UNCED 1992: 5; Sachs 1993). It should be emphasized that all the diagnosed problems are visible in modern cities, especially those which play the role of regional, national or international metropolises. An important challenge facing public policies, including urban development policies, is to combine the challenges of sustainable development with the expectations of citizens in terms of quality of life.

Quality of life is a multidimensional notion and phenomenon, emotionally burdened, often of an ideological tool character, an evaluative notion, impossible to grasp unequivocally, entangled in political and cultural contexts (Adamiec, Popiołek 1993). The term "quality of life" has a relatively short history, dating back to the 1960s. Previously, it did not appear often in public debate, although the issues connected with it, mainly concerning the search for the determinants of a happy and valuable life, have been accompanying the man since ancient times. Today it has become a permanent fixture in the terminology of such sciences as: sociology, medicine, economics, psychology, pedagogy.

Life aspirations are defined as the pursuits, intentions, needs and interests of an individual, which determine his or her behavior and plans, as well as influence his or her future life path. They are usually determined by psychological, sociological or pedagogical factors. Theoretically, they are also linked to the value system adopted by the entity (Musialska 2008).

The paper will present the results of a study conducted in 2018 in Rzeszow (Poland) and Lviv (Ukraine) entitled "The quality of life, personal and professional aspirations of students in Poland and Ukraine". The factors influencing the assessment of the quality of life in Rzeszow and Lviv as well as the personal and professional aspirations of students in Poland and Ukraine will be analysed.

\section{Area under Study}

The University of Rzeszow is a public Polish university with its seat in Rzeszow, the capital of the Podkarpackie Region. It is the largest academic university in southeastern Poland. The University of Rzeszow was established on 1 September 2001 as a result of the merger of three existing higher education institutions in Rzeszow, i.e. the Higher School of Pedagogy, a branch of the Maria Curie-Skłodowska University and the Faculty of Economics of the Agricultural Academy. However, the history of the university dates back to 1965, when the Higher School of Pedagogy was established with its seat in Rzeszow. In 1969, a branch of the Maria Curie-Skłodowska University in Lublin was established in Rzeszow, and in 1973, the Faculty of Agricultural Production and Trade Economics of the Hugon Kołłąaj University of Agriculture in Kraków was created. These three elements are the components of today's University of Rzeszow. In 2018, 16,607 students studied on the 12 faculties of the university (Higher 2018: 71).

Lviv University (the full name of the university is: Ivan Franko National University of Lviv) is a Ukrainian university, established in 1661 under the name of the Lviv Academy 
from a Jesuit College, which was established in Lviv in 1608, by the foundation act of the Polish King John II Casimir. In the years 1918-1939 it operated under the name of the Jan Kazimierz University. Lviv is the capital of the Lviv region and the largest city in western Ukraine. Since 1944 the University of Lviv is named after Ivan Franko. In 2018, 19,614 students studied at 19 faculties and three colleges.

\section{Methodology}

The main aim of the research was to learn the opinions of students of the University of Rzeszow and the Ivan Franko University of Lviv on selected topics related to the quality of life in Rzeszow and Lviv, as well as the personal and professional aspirations of students in Poland and Ukraine. The purpose of the study was both cognitive and practical, i.e. on the one hand it focused on obtaining information on specific topics related to various aspects of the quality of life in the city and the aspirations of young people, and on the other hand it attempted at obtaining information that could be useful for both university and city authorities in the context of exploiting the significant potential of young people living in these cities.

A wide range of research issues related to problems related to the quality of life and aspirations of students forced to narrow down the scope to a few basic areas of research. For the purpose of the research, detailed indicators describing the quality of life in several dimensions: safety in the city, transport and communication system, cultural offer, possibilities of spending free time or the labour market were used as variables determining the general index of students' quality of life in Rzeszow and Lviv. The detailed indicators were: 1) Rzeszow/Lviv is safe; 2) Rzeszow/Lviv has a rich cultural offer; 3) Rzeszow/Lviv has enough green areas (e.g.: parks, squares); 4) Rzeszow/Lviv has good conditions for sports and recreation; 5) Rzeszow/Lviv has well-kept streets and pavements; 6) Rzeszow/Lviv has good access to public transport; 7) Rzeszow/Lviv has too many shopping malls; 8) Rzeszow/Lviv is a well-kept city; 9) Rzeszow/Lviv is well managed; 10) it is easy to find a parking space in the city centre; 11) Rzeszow/Lviv allows to live well; 12) Rzeszow/Lviv offers good jobs; 13) Rzeszow/Lviv has enough bicycle lanes; 14) Rzeszow/Lviv has a good gastronomy offer (e.g. restaurants, pubs, coffe houses, pizzerias); 15) Rzeszow/Lviv is easy to commute by bike; 16) Rzeszow/Lviv is easy to commute on foot; 17) Rzeszow/Lviv is easy to commute by car; 18) Rzeszow/Lviv is a city to be proud of; 19) the municipal Police performs its duties well; 20) the number of Police patrols in Rzeszow/Lviv is sufficient.

The quality of life in the city was also evaluated in five aspects: 1) city safety, 2) transport system and infrastructure, 3) cultural offer and leisure activities, 4) city management and 5) job opportunities - labour market. Detailed indicators for the assessment of the safety level in the city were: 1) Rzeszow/Lviv is safe; 3) the municipal Police performs its duties well; 4) the number of police patrols in Rzeszow/Lviv is sufficient. For the rating of the communication system and transport infrastructure: 1) Rzeszow/Lviv has well-kept streets and pavements; 2) Rzeszow/Lviv has good access to public transport; 3) it is easy to find a parking space in the city center; 4) Rzeszow/Lviv has enough bicycle lanes; 5) Rzeszow/Lviv is easy to commute by bike; 6) Rzeszow/Lviv is easy to commute on foot; 7) Rzeszow/Lviv is easy to commute by car. The cultural offer and leisure 
opportunities were evaluated on the basis of the following indicators: 1) Rzeszow/Lviv has a rich cultural offer; 2) Rzeszow/Lviv has enough green areas (parks, squares); 3) Rzeszow/Lviv has good conditions for sports and recreation; 4) Rzeszow/Lviv has too many shopping malls; 5) Rzeszow/Lviv has a good gastronomy offer (restaurants, pubs, coffee houses, pizzerias). The quality of city management was based on two indicators: 1) Rzeszow/Lviv is a well-kept city and 2) Rzeszow/Lviv is well managed. The rating of the local labour market was based on the "Rzeszow/Lviv offers good jobs" indicator.

A general quality of life indicator was prepared to measure the quality of life in the city. It consisted of 20 statements presented above - partial indicators. Each of the indicators has been assigned indices. The indicators ranged from 1 to 5 , where " 1 " meant no acceptance of the statement and the lowest grade, and "5" meant full acceptance of the statement and the highest grade. "Hard to say" answers have been assigned a value of " 3 ". The sum of scores of partial elements was divided by 20 (number of variables, statements used to construct the indicator) and fell within the range of values from 1 to 5. For particular aspects of urban life: safety, transport system and infrastructure, cultural and leisure offer, city management or labour market, the same procedure was applied as for the overall quality of life indicator.

The aspirations of Polish and Ukrainian students related to their educational and professional goals and plans were diagnosed with the use of four indicators: 1) I study in Rzeszow/Lviv only temporarily, I intend to continue my studies elsewhere; 2) I intend to take up a job during my studies in order to gain professional experience; 3) I intend to go abroad under student exchange during my studies; 4) I believe that after completing my present faculty I may have serious problems with finding a job. The indicators assumed values from 1 to 5 , where " 1 " meant a strong acceptance of the statement, while " 5 " meant a strong rejection of the statement. "Hard to say" answers have been assigned a value of " 3 ".

\subsection{Participants and Procedure}

The research was conducted with the use of an audit questionnaire distributed among students of the same or similar fields of study at the faculties of the University of Rzeszow and the Ivan Franko University of Lviv. A total of 2208 questionnaires were conducted - 1789 at the University of Rzeszow and 419 at the Ivan Franko University in Lviv. The collected research material was coded and analyzed with the use of IBM SPSS Statistics 25 software, licensed by the Institute of Sociology. The results of the study were compiled into a statistical summary, using a t-test for independent samples, Etasquared $\left(\eta^{2}\right)$ and Chi-squared test.

Table 1. Characteristics of the test sample

\begin{tabular}{|l|l|c|c|}
\hline Demographic variables & Categories & Number of responses & Percentage of responses (\%) \\
\hline \multirow{2}{*}{ Gender } & Female & 1467 & 67.7 \\
\cline { 2 - 4 } & Male & 701 & 32.3 \\
\hline \multirow{2}{*}{ Place of residence } & City & 1113 & 51.6 \\
\cline { 2 - 4 } & Village & 1044 & 48.4 \\
\hline \multirow{2}{*}{ Nationality } & Polish & 1789 & 81.1 \\
\cline { 2 - 4 } & Ukrainian & 419 & 18.9 \\
\hline
\end{tabular}


As can be seen from Table 1, the sample was dominated by women, who constituted two thirds of the surveyed students - 67.7\% ( $n=1467)$. Male students constituted one third of the respondents $-32.3 \%(n=701)$. A small majority of the respondents before starting their studies lived in cities - 51.6\% $(\mathrm{n}=1113)$ compared to villages - 48.4\% $(n=1044)$. The vast majority of the respondents were students from Poland - 81.1\% $(n=1789)$. Every fifth examined student came from Ukraine - 18.9\% $(n=419)$.

\section{Results}

In order to verify the research hypothesis assuming that the students of the University of Rzeszow rate the quality of life in Rzeszow much higher than the students of the Ivan Franko University of Lviv, the t-test for independent samples was applied with the use of IBM SPSS Statistics 25 software. As the results of Table 2 show, the hypothesis has been confirmed. Slightly higher overall quality of life in the city was noted among students from Rzeszow 3,611 (SD=0.499) compared to Lviv 3,513 (SD=0.506). The difference in the quality of life score is statistically significant $t=3.434(p<.001)$. As the eta-squared presented in Table 3 shows, the strength of the relationship is average $(\eta 2=.006)$.

Table 2. T-test for independent samples - assessment of the quality of life in the city

\begin{tabular}{|c|c|c|c|c|c|c|}
\hline \multicolumn{2}{|l|}{ Measures } & Mean & SD & $\mathrm{t}$ & $\mathrm{df}$ & Sig. \\
\hline \multirow{2}{*}{ Safety } & Rzeszow & 3.454 & 0.661 & \multirow{2}{*}{1.949} & \multirow{2}{*}{2156} & \multirow{2}{*}{.051} \\
\hline & Lviv & 3.383 & 0.699 & & & \\
\hline \multirow{2}{*}{ Cultural and leisure activities } & Rzeszow & 3.812 & 0.668 & \multirow{2}{*}{-10.809} & \multirow{2}{*}{2146} & \multirow{2}{*}{.000} \\
\hline & Lviv & 4.205 & 0.636 & & & \\
\hline \multirow{2}{*}{ Communication and transport } & Rzeszow & 3.532 & 0.569 & \multirow{2}{*}{16.524} & \multirow{2}{*}{571.219} & \multirow{2}{*}{.000} \\
\hline & Lviv & 2.969 & 0.622 & & & \\
\hline \multirow{2}{*}{ City management } & Rzeszow & 3.882 & 0.773 & \multirow{2}{*}{12.765} & \multirow{2}{*}{2162} & \multirow{2}{*}{.000} \\
\hline & Lviv & 3.338 & 0.795 & & & \\
\hline \multirow{2}{*}{ Labour market } & Rzeszow & 3.330 & 0.845 & \multirow{2}{*}{-8.887} & \multirow{2}{*}{2171} & \multirow{2}{*}{.000} \\
\hline & Lviv & 3.743 & 0.874 & & & \\
\hline \multirow{2}{*}{ Overall assessment of the quality of life } & Rzeszow & 3.611 & 0.499 & \multirow{2}{*}{3.434} & \multirow{2}{*}{1952} & \multirow{2}{*}{.001} \\
\hline & Lviv & 3.513 & 0.506 & & & \\
\hline
\end{tabular}

The analysis of individual aspects of the quality of life in the city also brings interesting results. The biggest differences in the assessment of individual aspects of urban life can be seen in the assessment of the transport system and infrastructure $t=16.524(\mathrm{p}<.000)$. Students from Rzeszow rated the city's transport system much better - 3.532 (SD=0.569) than their colleagues from Lviv - 2.969 ( $\mathrm{SD}=0.622)$. The strength of the relationship is very high $\left(\eta^{2}=.128\right)$. Statistically significant differences in the assessment of particular aspects of the quality of life occur in the case of: city management $t=12.765(p<.000)$, cultural and leisure offer $\mathrm{t}=-10.809(\mathrm{p}<.000)$ and the rating of the local labour market $\mathrm{t}=-8.887(\mathrm{p}<.000)$. Rzeszow students rated the city management better - 3.882 $(\mathrm{SD}=0.773)$ than the students from Lviv - $3.338(\mathrm{SD}=0.795)$; same was true for the local labour market - $3.330(\mathrm{SD}=0.845)$ vs $3.743(\mathrm{SD}=0.874)$. Lviv students have a better opinion of the city's cultural offer and leisure time opportunities $4.205(\mathrm{SD}=0.636)$ than 
students from Rzeszow 3.812 ( $\mathrm{SD}=0.668$ ). As shown in Table 3, the strength of the etasquared relationship for all the three aspects was very strong.

Table 3. Eta and eta-squared - rating of the quality of life in the city

\begin{tabular}{|l|c|c|}
\hline Measures & Eta $(\eta)$ & Eta-squared $\left(\eta^{2}\right)$ \\
\hline Safety & .042 & .002 \\
\hline Cultural and leisure activities & .227 & .052 \\
\hline Communication and transport & .358 & .128 \\
\hline City management & .265 & .070 \\
\hline Labour market & .187 & .035 \\
\hline Overall assessment of the quality of life & .077 & .006 \\
\hline
\end{tabular}

Personal aspirations concerning educational and professional goals and plans show significant differences. Students from Rzeszow have a slightly higher 4,066 (SD=1.227) than students from Lviv $3.952(\mathrm{SD}=1.280)$ rejection rate for the statement that they are studying in Rzeszow/Lviv only temporarily and intend to continue their studies elsewhere. The difference in the t-test level for independent samples between students from Rzeszow and Lviv was not statistically significant, $t=1.652(p<.099)$. However, statistically significant were the differences in the students' aspirations to take up employment during their studies: $\mathrm{t}=3.579(\mathrm{p}<.000)$, intention to go abroad during their studies $\mathrm{t}=7.957(\mathrm{p}<.000)$ and serious problems with finding a job after graduation $\mathrm{t}=2.135(\mathrm{p}<.033)$.

Table 4. T test for independent samples - life and professional aspirations

\begin{tabular}{|c|c|c|c|c|c|c|}
\hline Measures & & Mean & SD & $\mathrm{t}$ & $\mathrm{df}$ & Sig. \\
\hline I study in Rzeszow/Lviv only temporarily, I intend to & Rzeszow & 4.066 & 1.227 & 1652 & & $0 c^{-}$ \\
\hline continue my studies elsewhere & Lviv & 3.952 & 1.280 & 1.032 & 0 & \\
\hline I intend to take up employment during my studies in & Rzeszow & 2.691 & 1.245 & 3579 & 50367 & 08 \\
\hline order to gain professional experience & Lviv & 2.432 & 1.340 & 3.517 & (595.01 & 0 \\
\hline I intend to go abroad under student exchange during & Rzeszow & 3.450 & 1.253 & 7057 & 589005 & 00 \\
\hline my studies & Lviv & 2.865 & 1.368 & & & \\
\hline I believe that after completing my present faculty I & Rzeszow & 3.447 & 1.220 & 2) 135 & 503065 & $0333-2$ \\
\hline may have serious problems with finding a job. & Lviv & 3.296 & 1.320 & & & \\
\hline
\end{tabular}

Lviv students are more likely to take up employment during their studies to gain work experience $2.432(\mathrm{SD}=1.340)$ than their Rzeszow colleagues 2.691 ( $\mathrm{SD}=1.245)$. As shown in Table 5 , the strength of the relationship is average $\left(\eta^{2}=.006\right)$. The biggest differences in terms of personal plans and intentions concerned the intention to go abroad during studies. Students from Lviv were much more willing to do so 2.865 $(\mathrm{SD}=1.368)$ than students from Rzeszow 3,450 $(\mathrm{SD}=1.253)$. The strength of the relationship with this indicator is very high $\left(\eta^{2}=.032\right)$. Slightly more skeptical in the belief that after graduation they may have serious problems with finding a job are students from Lviv $3.296(\mathrm{SD}=1.320)$ than from Rzeszow 3.447 (SD=1.220), but the strength of the relationship is small $\left(\eta^{2}=.002\right)$. 
Table 5. Eta and eta-squared - personal and professional aspirations

\begin{tabular}{|l|c|c|}
\hline Measures & Eta $(\eta)$ & Eta-squared $\left(\eta^{2}\right)$ \\
\hline $\begin{array}{l}\text { I study in Rzeszow/Lviv only temporarily, I intend to } \\
\text { continue my studies elsewhere }\end{array}$ & .036 & .001 \\
\hline $\begin{array}{l}\text { I intend to take up employment during my studies in } \\
\text { order to gain professional experience }\end{array}$ & .080 & .006 \\
\hline $\begin{array}{l}\text { I intend to go abroad under student exchange during my } \\
\text { studies }\end{array}$ & .178 & .032 \\
\hline $\begin{array}{l}\text { I believe that after completing my present faculty I may } \\
\text { have serious problems with finding a job }\end{array}$ & .048 & .002 \\
\hline
\end{tabular}

\section{Discussion and Conclusion}

In the 1960s and 1970s two directions evolved for considering issues associated with quality of life. Within the scope of the first, the phrase "quality of life" was used as a value determinant. The rising outcry against the consumer society in the United States brought with it a growing popularity of an alternative lifestyle. Its proponents propagated a new quality of life. They opposed economic development solely geared towards increasing consumption, one which destroys the natural environment and social ties. The second direction for considering the quality of life issue, referred to as the social indicators movement by Otis Duncan, takes root in the field of social research. The quality of life concept which emerged from this field, identified it with indices measuring the material standard of life and/or life satisfaction levels. A vibrant discourse is still underway to this day within that field, concerning indicators measuring quality of life on individual as well as population levels. The gross national income per capita is generally adopted as a quality of life measure, although many authors point out the limitations of such an index. The main criticism concerns the fact that income does not reflect cultural differences. Neither does it reflect the distributive nature of an economy. It does not take into account the fact that when it comes to financial situations, modern societies are internally diverse (Rokicka, 2013: 159-160).

Representatives of numerous scientific disciplines including pedagogy, psychology, sociology and medicine show an avid interest in the quality of life concept which, on the one hand, ensures it is considered in a multifaceted complementary manner from a multidisciplinary perspective, whilst on the other, it leads to a multiplicity of different understandings of the concept and in turn inconsistencies in its operationalization (Petelewicz, Drabowicz, 2016: 13). Ewa Rokicka, in her attempt to systematize various quality of life areas of interest, identified five primary trends:

1) a trend focusing on the protection of the natural environment - depicts the consequences of civilizational progress for the natural environment, human health and quality of life, amongst others as a result of air, water and noise pollution, etc.;

2) a trend associated health measures - in medicinal sciences, Health Related Quality of Life (HRQoL), understood as a patient's self-assessment pertaining to the impact of an illness and the administered treatment on their physical, psychological and social functioning, is looked upon as a health measure on par with medical health measures. The HRQoL index shows whether, despite an illness, a patient perceives themselves to function well within the aforementioned scopes, or whether they consider the illness to 
restrict those functions;

3) a trend which pertains to urbanisation issues - here, attention is particularly devoted to unfavourable consequences of scientific and technological progress within urban areas, such as: incorrect spatial planning for cities, residential accommodation, excessive vehicular traffic, high density of urban agglomerations;

4) a trend based on social and psychological motives - focuses on the negative consequences of civilizational progress for individuals and the social life; these include: self-alienation, social alienation, estrangement, emptiness and loneliness experienced by people;

5) a trend which focuses on the economic aspect of life - quality understood as the living standard of an individual, local, regional, national or international communities, it may be interchangeably treated as a dependent variable as well as the independent variable, as a factor determining economic development and the results thereof. The level of wealth and poverty and their unequal distribution are significant for the individual's and society's quality of life (Rokicka, 2013: 161).

It should be pointed out that a two-fold approach to quality of life is evident in all five trends. On the one hand, it may be seen as a value determinant of a comparative nature, and on the other, as descriptive and not determining value. To a certain extent, the quality of life issue itself is a value determinant. Both authors as well as those who assess their own quality of life represent various philosophical notions on life, different ideological orientations, their moral values' hierarchies as well as life experiences which affect psyche are diverse. They judge according to their own criteria, knowledge, standards and comparative points of reference (Rokicka, Petelewicz, 2014: 144). An important distinction was formulated under the descriptive approach between an objective and subjective quality of life, which almost all researchers of the issues in question refer to. Factors such as standard of living, financial and housing conditions as well as health constitute the objective dimension of quality of life. It is usually understood as a set of conditions for human existence and activity (Rokicka, 2013: 161162). Elements associated with satisfaction derived from particular aspects of human existence, health, ways of spending free time, social position or human existence as a whole make up the subjective dimension (Ostasiewicz, 2004: 63-64). Even though both sets of factors are taken into account in quality of life research, there is no clear boundary between the two, nor is it clear which elements make up the subjective context, which indices should be used to measure them and what the relations are between the subjective and objective indices. The objective quality of life aspect is most often identified with welfare and the subjective one with well-being. Research on wellbeing differs from research on welfare in the use of survey techniques, which facilitate the discovery of the respondents' opinions on their life (Rokicka, 2013: 162).

The issue of quality of life is a part of the idea of sustainable development. Certainly an important challenge facing public policies, including urban development policies, is to combine the challenges of sustainable development with the expectations of citizens in terms of quality of life. Research on the future creative class - students - is a very important element of the diagnosis of the needs of the inhabitants and the assumptions of public policies.

The main research hypothesis was the assumption that the students of the University of 
Rzeszow rate the quality of life in Rzeszow much higher than the students of the Ivan Franko University of Lviv. The hypothesis has been confirmed. Also the analysis of individual aspects of the quality of life brought interesting conclusions. Students from Rzeszow rate much higher than their Lviv counterparts the public transport, transport system and city management than their colleagues from Lviv. The cultural and leisure offer and the labour market are rated lower, on the other hand. The assessment of the safety level in the city is not differentiated.

The respondents also showed differences in the students' personal aspirations. Those surveyed in Lviv are more likely to think about going abroad while studying, taking up employment during their studies, and changing their place of study to another city. They are also more optimistic about the chance of finding a job after they have finished their course.

The results of the research can be useful for both city and university authorities. Diagnosis of the quality of life in the city may be particularly important from the point of view of urban development policy planning as future university graduates are intellectual elite and creative class, which will be the foundation of human capital living in Rzeszow and Lviv. It is also important to note that Rzeszow and Lviv are partner cities, capital cities of two neighbouring regions - Podkarpackie and Lviv. Cooperation between the neighbours and partner cities should also be based on the exchange of experiences, ideas and pro-development impulses. This also applies to the two largest universities in these cities - the University of Rzeszow and the University of Lviv.

\section{References}

Adamiec M.. Popiołek K. (1993). Jakość życia - miedzy wolnością a mistyfikacją. Ruch Prawniczy. Ekonomiczny i Socjologiczny. No 2. 93-102.

Barber. J. (2003). Production. Consumption and the World Summit on Sustainable Development. Environment. Development and Sustainability 5: 63. https://doi.org/10.1023/A:1025319915498.

Higher education institutions and their finances in 2017 (2018). Główny Urząd Statystyczny. Urząd Statystyczny w Gdańsku. Warszawa - Gdańsk.

Keating M. (1993). The Earth Summit's agenda for change: a plain language version of Agenda 21 and the other Rio agreements. Centre for Our Common Future. Geneva.

Leisinger K. (1998). Sustainable development at the turn of the century: perceptions and outlook. International Journal of Sustainable Development. Vol. 1. No 1. 73-98.

Moffatt I. (1996). Sustainable Development: Principles. Analysis and Policies. The Parthenon Publishing Group. New York - London.

Musialska K. (2008). Aspiracje życiowe młodzieży stojącej u progu dorosłości. Oficyna Wydawnicza „Impuls”. Kraków.

Nasza wspólna przyszłość. Raport Światowej Komisji do Spraw Środowiska i Rozwoju (1991). Państwowe Wydawnictwo Ekonomiczne. Warszawa.

Ostasiewicz W. (2004). Ocena i analiza jakości życia. Wydawnictwo Uniwersytetu Ekonomicznego. Wrocław.

Pearce D.. Markandya A. \& Barbier E.B. (1989). Blueprint for a green economy. Earthscan. London.

Petelewicz M., Drabowicz T. (2016). Jakość życia - globalnie i lokalnie: Pomiar i wizualizacja. General Sociology Department. Faculty of Economics and Sociology. University of Lodz. Lódź.

Pluta J. (2010). Jakość i styl życia a system konsumpcji zbiorowej we Wrocławiu. In: Problemy społeczne w przestrzeni Wrocławia. (edited by): M. Błaszczyk, S.W. Kłopot, J. Pluta, Wydawnictwo Naukowe Scholar. Warszawa. 
Rokicka E. (2013). Jakość życia - konteksty, koncepcje, interperetacje. In: Nowy Lad? Dynamika struktur społecznych we współczesnych społeczeństwach. Księga pamiątkowa poświęcona Profesor Wielisławie Warzywodzie-Kruszyńskiej z okazji 45-lecia pracy naukowej i dydaktycznej. (edited by): J. Grotowska-Leder, E. Rokicka. Wydawnictwo Uniwersytetu Lódzkiego. Łódź.

Rokicka E., Petelewicz M. (2014) Subiektywna jakość życia a status społeczno-ekonomiczny. Na przykładzie mieszkańców Łodzi. "Przegląd Socjologiczny", No. 63/2014(2).

Sachs I. (1993). Strategie transformacji u progu XXI wieku. Polskie Towarzystwo Współpracy z Klubem Rzymskim. Warszawa.

Serageldin I. (1995). Evaluating environmentally sustainable development. In: Evaluation and Development. Proceedings of the 1994 World Bank Conference. (edited by): R. Picciotto and R.C. Rist. The World Bank. Washington. 23-43.

Trzebiatowski J. (2011) Jakość życia w perspektywie nauk społecznych i medycznych - systematyzacja ujęć definicyjnych. "Hygeia Public Health" No. 46(1).

UNCED - United Nations Conference on Environment and Development (1992). The Rio Declaration on Environment and Development. (http://www.unesco.org/education/pdf/RIO_E.PDF).

UNCSD - United Nations Commission on Sustainable Development (1997). Overall Progress Achieved Since the United Nations Conference on Environment and Development: Changing Consumption Patterns. United Nations Commission on Sustainable Development. Fifth session 7-25 April 1997. United Nations. New York. 